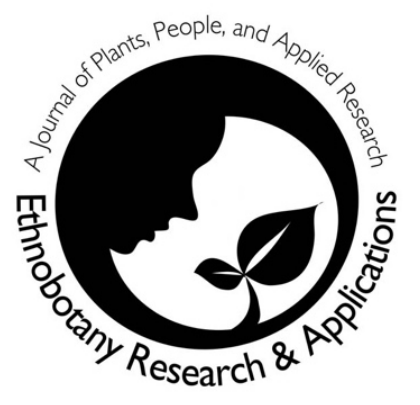

\title{
Mixtec taxonomy: plant classification, nomenclature, and identification in Oaxaca, Mexico
}

\author{
Juan Carlos Aparicio Aparicio, Robert A. Voeks and Ligia \\ Silveira Funch
}

\section{Research}

\begin{abstract}
Background: Ethnotaxonomy seeks to understand how members of a culture name and categorize biological organisms in their local language. This research examined the ethnotaxonomy of plants among the Mixtec people in the municipality of San Miguel el Grande, Oaxaca, Mexico.
\end{abstract}

Methods: We conducted a collaborative research between 2019 and 2020 with 42 Mixtec men and women between 38 and 100 years of age, in the ten communities that make up the municipality. We focused on classification, nomenclature and plant identification.

Results: There is a more or less hierarchical classification that contemplates both cognitive and utilitarian aspects. The nomenclature shows that the Mixtec of the study area have taken into account the characteristics of the plants-cultural, experiential, and ecological-to name them. Identification is based on multiple morphological, ecological, cultural and experiential mechanisms.

Conclusion: The botanical ethnotaxonomy of San Miguel el Grande is rich and varied, revealing that plants play an important role in the lives of people. However, it seems that the disuse of some plants and the Spanish language is conditioning the maintenance of Mixtec plant names.

Keywords: Folk taxonomy, Mixtec region, ethnobotany, Mixtec language, ethnotaxonomy.

\section{Background}

Ethnotaxonomy shows how members of a culture nominate and categorize biological organisms in their local language (Brown 2000). Studies the logical organization of an organism in the mind of an individual (classification), the linguistic description of the conceptual categories recognized in that language (nomenclature) and, the recognition of the physical characteristics used to place an organism in a category specifies (identification) (Berlin 1973).

\section{Correspondence}

Juan Carlos Aparicio Aparicio ${ }^{1^{*}}$, Robert A. Voeks $^{2}$, Ligia Silveira Funch ${ }^{1}$

1Departamento de Ciências Biológicas, Universidade Estadual de Feira de Santana, Transnordestina, s/n, Novo Horizonte, 44036-900, Feira de Santana, BA, Brazil.

${ }^{2}$ Department of Geography \& the Environment, California State University, USA

*Corresponding Author: charly_jan92@hotmail.com

Ethnobotany Research \& Applications

21:24 (2021)

Plants were the first organisms to be explored in ethnotaxonomic studies. In 1905, the botanist Barbosa-Rodrigues emphasized that the native peoples of Brazil who spoke the language he called abanheenga, named plants with a binomial nomenclature and classified them into genera and families. Later in 1940 Moisés Bertoni showed the same results for the Guaraní of Paraguay. But the first to formally address cognitive concepts and categories, as well as the importance of nomenclature, was the anthropologist Harold Conklin in his important ethnobotanical work with the Hanunoo of the Philippines (Conklin 1954).

Around 1960, various studies began to approach the classifications with a structuralist and universalist perspective. One of the most important works was 
that of the anthropologist Brent Berlin and his colleagues who argued that the different cultures of the world cognitively organize plants and animals in the same way (Berlin et al. 1973). They established that there are five, sometimes six, universal ethnobiological taxonomic categories in popular classification, arranged hierarchically and with mutually exclusive taxa, and which also present a certain degree of equivalence with Linnaean taxonomy (Berlin 1992). Two important aspects that characterize this current of thought (cognitivist) are: 1) that classification is governed by intellectual principles such as an innate human need to organize the world (Tyler 1969) or by simple curiosity (Berlin 1992), and 2) that the categorization of taxa usually is based on morphological similarities and differences. This contrasts with a second (utilitarian) current of thought that argues that classification is strongly influenced by the utilitarian character of plants (Hunn 1982). The two approaches have been tested in ethnotaxonomical studies with results partially defending both (Boster 1985, Brown 1985, Galeano 2000, Voeks \& Nyawa 2006). In this way, other authors have proposed an approach between both currents (Atran 1998, Clément 1995) considering that the traditional classifications systems has much more complex implications as cultural aspects in a broad sense (Hays 1982), ecological (Balakrishnan et al. 2003, Kakudidi 2004), or experiential (Newmaster et al. 2007).

Ethnotaxonomical studies are important because they help us understand the way in which the different cultures of the world perceive and manage their natural environment, in addition to helping us to better understand biological diversity. In Mexico, various cultures have contributed relevant knowledge to the discussions on traditional classification systems, starting with the important works led by Berlin, the findings in the Mayan culture for example, were the basis for the formulation of the Berlinean classificatory model (Berlin 1992). However, not all cultural groups have been properly studied, the Mixtec culture of Oaxaca is one in which minimal studies have been developed with a mere ethnotaxanomic approach, in relation with plants (for example, De Ávila 2010, Katz 1997). In particular, the work of De Ávila 2010 is of great importance since it is a review of a large part of the Mixtec region, this contribution is fundamental to support our research that emphasizes the presentation of a Mixtec classification model, while they are discussed new ethnotaxonomic data for the Mixtec. The objective of this article is to show an overview of the traditional plants classification system in a community of the Mixtec region, in Mexico. We take into account the two approaches in ethnotaxonomical studies, the cognitivist and the utilitarian, using Berlin's concepts but also showing how utilitarian and other aspects are important in classification. We discuss the Mixtec nomenclature of the study area and the different criteria that people take into account to form Mixtec names. Finally we show that people use different mechanisms to identify plants.

\section{Materials and Methods Study Area}

The Mixtec region encompasses part of three states in southern Mexico: Puebla, Guerrero, and Oaxaca. The Mixtec or $\tilde{N} u u$ savi (people of the rain), speak the Mixtec language of the Otomangue linguist family and are the third group with the largest number of speakers of a native language in Mexico (INALI 2010). Based on altitude, the region is divided into three important sub-regions: the "Mixteca de la Costa" or Nudeui (foot of the sky); the "Mixteca Baja" or Ñuiñe (hot land) and the "Mixteca Alta" or Ñu Savi Ñuhu (divine place).

Our study was carried out in the communities of the municipality of San Miguel el Grande located to the west of the high Mixtec subregion (UTM 14Q 646792 West and 1885242 North; Datum WGS84), in the state of Oaxaca, Mexico (Figure 1). It has an average annual temperature of $12^{\circ} \mathrm{C}$; annual precipitation varies between 800 and 1000 mm (INEGI 2005). According to the Köppen classification, modified by García (2004), the climate of the municipality is temperate subhumid with rains in summer $C\left(w_{2}\right)(w)$, this climate is characterized by its high humidity in the rainy season and a dry winter. Two seasons of the year are clearly defined: the rainy season from May to October and the dry season from October to May, approximately. Vegetation is dominated by pine-oak forest (Pinus spp. and Quercus spp.). In the high elevations it is complemented with species of fir (Abies spp.), and in the lower part with species of juniper (Juniperus flaccida Schltdl.) and madrone (Arbutus xalapensis Kunth), as well as alder (Alnus acuminata Kunth), ash (Fraxinus uhdei (Wenz.) Lingelsh.), Montezuma cypress (Taxodium mucronatum Tem.), and willow (Salix spp.) in the riparian zone.

The Mixtec in the study area are a mountain people. In 2010 there were 2223 women and 1904 men (INEGI 2010). They maintain the traditional cultivation of the milpa (corn (Zea mays L.), beans (Phaseolus lunatus L.; Phaseolus vulgaris L.), squash (Cucurbita pepo L.; Cucurbita ficifolia Bouché), and broad beans (Vicia faba L.)) but currently incorporate a lot of chemical fertilizer to the crops and have replaced work animals (oxen) with tractors to plow the land (Aparicio 2019a). They take advantage of many plants for food and medicine, and also include a large number of wild insects and fungi 
in their diet (Aparicio 2019b, Costa-Neto \& Aparicio 2018).

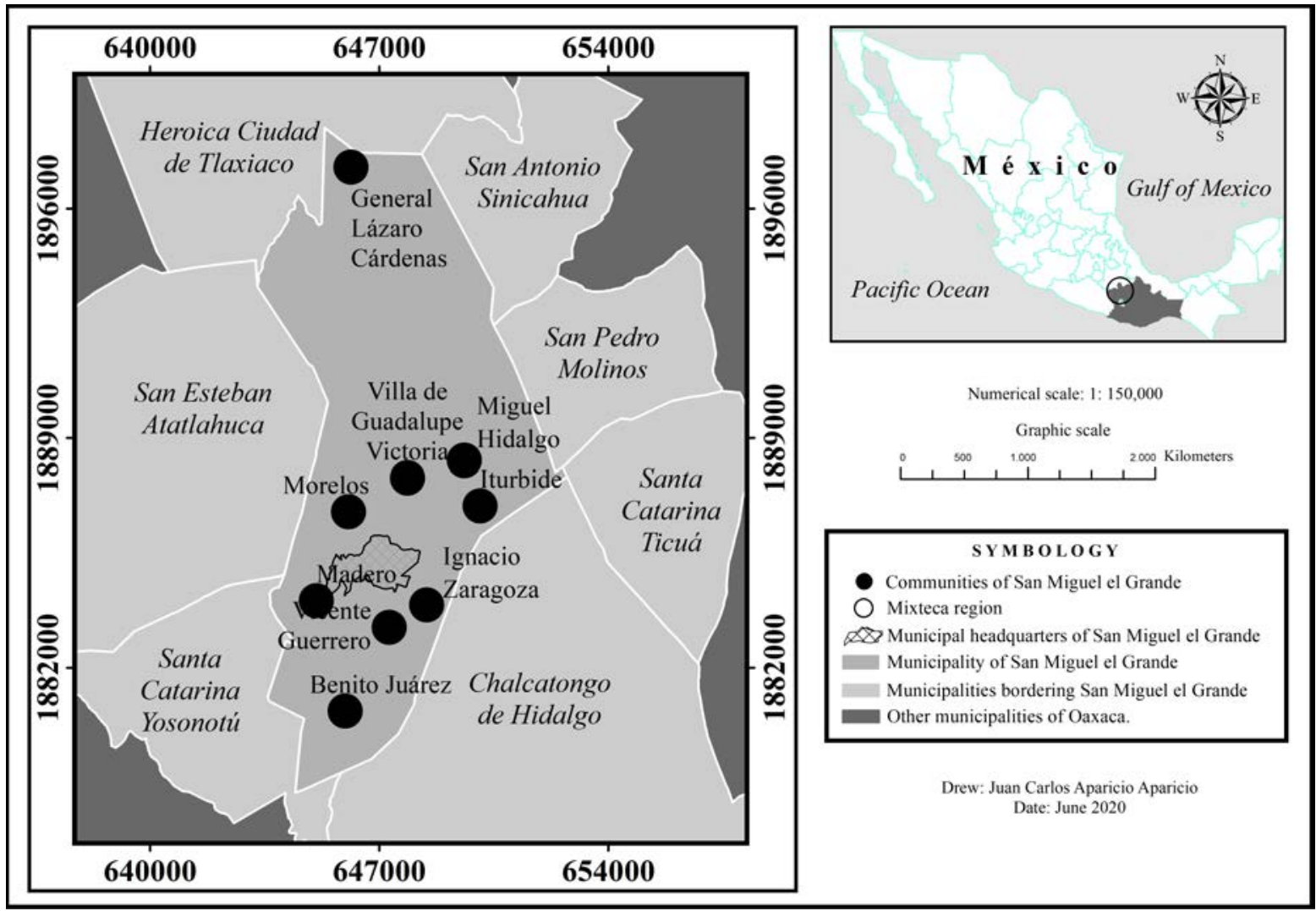

Figure 1. Location map of the study communities in the Mixtec region.

\section{Data collection and analysis}

The research took into account the principles of the code of ethics of the Latin American Society of Ethnobiology (Cano-Contreras et al. 2015) and the previous consensus with agrarian and municipal authorities of the study area. Informed consent was obtained verbally from all participants prior to the study.

The fieldwork was carried out during June 2019 and June 2020. We included 42 bilingual Mixtec men and women between 38 and 100 years of age. Previously, we made visits to some people from all the communities (with more than 200.) to establish informal talks on various aspects of natural resources. We included people who stated that they had extensive knowledge about plants in the Mixtec language and who were interested in participating in the study (we call these people Mixtec botanical experts, they are people with a specific function within the cultural group, be it a traditional doctor or just an experienced person). We spoke with all the people involved more than once according to their availability. We conducted open dialogues first (it was discussed; the origin, characteristics and diversity of plants from the perception of people, to try to understand the organization of plants in people's minds.), then semi-structured interviews on specific plants (for example; meaning of plant names, how many types there are, differences between similar plants, special characteristics, current and past uses.), and finally follow-up interviews in order to corroborate the information and clarify doubts (we asked the same questions of the same people at different times). With the 38 to 84 year olds, we took field trips to recognize plants in their habitats. We took the plants home for 85-100 year olds for identification. All of our dialogues with people generally lasted more than 2 hours and the tours sometimes all day. Given the time involved, some people received financial support of approximately $\$ 10$ United States dollars (USD). We supported other people with training on the natural control of pests that occur in their crops, on how to perform grafting on fruit trees, and we have also provided information on the properties of medicinal plants that people want to know. The research has been one of coexistence-collaboration, that is, we share knowledge and food, and help people in their activities as a form of contribution.

We collected plants in all communities, at altitudes from 2100 to $3300 \mathrm{~m} \mathrm{MSL}$. The plants have been scientifically identified using taxonomic keys from 
different bibliographic sources (Bravo-Hollis 1978, Calderon \& Rzedowski 2001, Farjon et al. 1997, Gentry 1982), with the aid of specialists and by comparison with previously identified material. All the plants of the genus Agave have been morphologically characterized in situ and have not been collected for preservation. Voucher specimens were deposited in the Herbarium of the National Autonomous University of Mexico (MEXU). The scientific nomenclature of plants is based on TROPICOS (http://www.tropicos.org/).

For the analysis of the classification we used some concepts developed by Berlin (1992). The classification model that we present is based on the perception of people and the names of the plants provided. We did not use a specific method to test the classification of the people, each person was approached individually and then we compared the responses to build the classification model, always taking into account the nomenclature. The Mixtec names were translated directly with the people since they were all bilingual. The ethnobiological taxonomic categories proposed by Berlin are: unique beginner, life form, generic, specific and varietal, the discontinuous units in each category are called taxa. Here, we name the last three categories: Mixtec generic, Mixtec specific, and Mixtec variety, respectively. We call the taxa ethnotaxa. Mixtec ethnotaxa are variable plant populations that are recognized by different mechanisms, depending on the agroclimatic conditions.

For nomenclature analysis, the theoretical assumptions of Conklin $(1954,1962)$ were taken into account. According to this author, names in traditional taxonomy are structured in lexemic units. These can be unit or compound lexemes; unit lexemes can be simple or complex. We must make distinctions between compound lexemes and complex unit lexemes. We use our Mixtec data to show this differentiation. Compound lexemes exhibit descriptive force; for example, the compound name nuyuja kuijin, "white pine" immediately reveals that it is a type of nuyuja "pine" that is distinguished from other pines by being lighter. In contrast, complex unit lexemes lack descriptive force; for example, the unit complex lexeme yáa sndiki "cow tongue" is not the name of a type of yáa "tongue": therefore, in this case we are dealing with a complex unit lexeme.

We use the correspondence analysis of Berlin (1992) to establish the relationship between Mixtec generics and Linnaean species, but we only exemplify the correspondence of over-differentiation, which refers to when two or more ethnobiological categories correspond to a single Linnaean species.

\section{Results and discussion}

\section{Mixtec classification of plants}

The Mixtec classification of San Miguel el Grande is hierarchical and can present up to five ethnobiological taxonomic categories: unique beginner, life form, Mixtec generic, Mixtec specific, and Mixtec variety. The Mixtec recognize all plants with the word tiyuku. This term is equivalent to the unique beginner. Plants can also be recognized with the term yuku, but this term is polysemic, referring to herbaceous plants and also to hill or mountain. Plants are recognized by their green color, and the word kui (green) refers to any green part of a plant. De Ávila (2010) in his study on the nomenclature of plants in the Mixtec language shows that among the different peoples who speak the Mixtec language, various terms such as yutũ or yuku are used to refer to plants in general. In the west of the high Mixtec subregion, yuku seems to be the most used term (Beaty et al. 2012, Pérez-Jiménez 2017).

We identify fourteen categories of life form, these are yunu (trees), yuku (herbaceous plants), yooyuku (vines), vincha (cacti), ximú (bromeliads), yau (agaves), xinú (green algae), icha (grasses), xio koó (horsetails), nuyoo (common reed), nduchi (legumes), nuni (corn), ita (many flowering plants), and a last category that designates edible plants but is not labeled with a Mixtec word. Of all life forms, according to Berlin (1992), only yunu (tree) and yuku (grass) are clearly life forms, since they immediately include Mixtec generic taxa. For example, yunu is immediately superior to nuyuja (Pinus spp.) and to nuyúkún (Taxodium ssp.). All other life forms have the formal characteristics of generics, that is, they immediately include specific taxa. We treat them as forms of life because the Mixtec perceive them as separate groupings, which are neither herbs nor trees, and the nomenclature is proper for each of them. Yunu is the most linguistically complex life form. It has derived nominal markers such as $n u$ and $n t$ that precede the name of many trees, shrubs and sub-shrubs. This observation is consistent in most Mixtec peoples where more markers can be found, such as tun, tnu, tu, ton, to, un, $t$, and ch (De Ávila 2010). It is also the most developed because it includes the five ethnobiological taxonomic categories while in the others, three or four generally occur. The yunu and yuku life forms have polysemic names and are the most important for the number of plants they include. Most other life forms generally include plant species of a Linnaean family or genus, with minor exceptions. For instance, the nduchi life form includes the beans but also includes the species Ricinus communis $L$. because of the similarity of their seeds. The least consistent life forms are ita (flowering plants) and yooyuku (lianas) because they encompass only certain plants. De Ávila (2010), mentions that the ita grouping in the 
Mixtec region generally includes plants with useful outstanding flowers. In San Miguel el Grande the ita way of life generally includes herbaceous, but also some shrubs and trees, such as the Senna multiglandulosa (Jacq.) H.S Irvin \& Barneby species, which is named as ita timi (flower of the bees).

The basic categories Mixtec (generic, specific and varieties) can refer to both species and Linnaean genera. There are a small number of terminal Mixtec generics, marked by a unitary lexeme that does not include other labeled categories and that refer to a genus or a Linnaean species. The most abundant categories are those of the Mixtec specific, they have binomial names and generally refer to an only
Linnaean species. The categories of Mixtec varieties are also few; they are represented by trinomial names and can be equivalent to species, subspecies or Linnaean varieties. Table 1 shows examples of these categories.

We have shown the five ethnobiological categories of the Mixtec classification of plants. In this classification, trees are the most developed life form. They present the five ethnobiological taxonomic categories, while in the others there are three to four. In Figure 2 we exemplify the Mixtec classification of edible trees and plants in a hierarchical model; the hierarchy is evident in linguistic terms, where one category is superordinate to another.

Table 1. Basic Mixtec categories and their equivalence in Linnaean taxonomy.

\begin{tabular}{|l|l|l|}
\hline Ethnobiological taxonomic categories & Scientific equivalence \\
\hline \multirow{3}{*}{ Mixtec Generic } & Nuyúndú & Arbutus xalapensis Kunth \\
\cline { 2 - 3 } & Nuíní & Juniperus flaccida Schltdl. \\
\cline { 2 - 3 } & Nuyísi & Persea americana Mill. \\
\hline \multirow{3}{*}{ Mixtec specific } & Nuyuja kuijín & Pinus pseudostrobus Brongn. \\
\cline { 2 - 3 } & Nuyuja chinu & Pinus lawsonii Roezl ex Gordon \\
\cline { 2 - 3 } & Nuyuja kuá'á & Pinus leiophylla Schiede ex Schltdl. \& Cham \\
\hline \multirow{3}{*}{ Mixtec varietal } & Itá limbée kuijín & Dahlia pinnata Cav. \\
\cline { 2 - 3 } & Itá limbée ndíí & Dahlia pinnata Cav. \\
\cline { 2 - 3 } & Itá limbée kuá'á & Dahlia pinnata Cav. \\
\hline
\end{tabular}

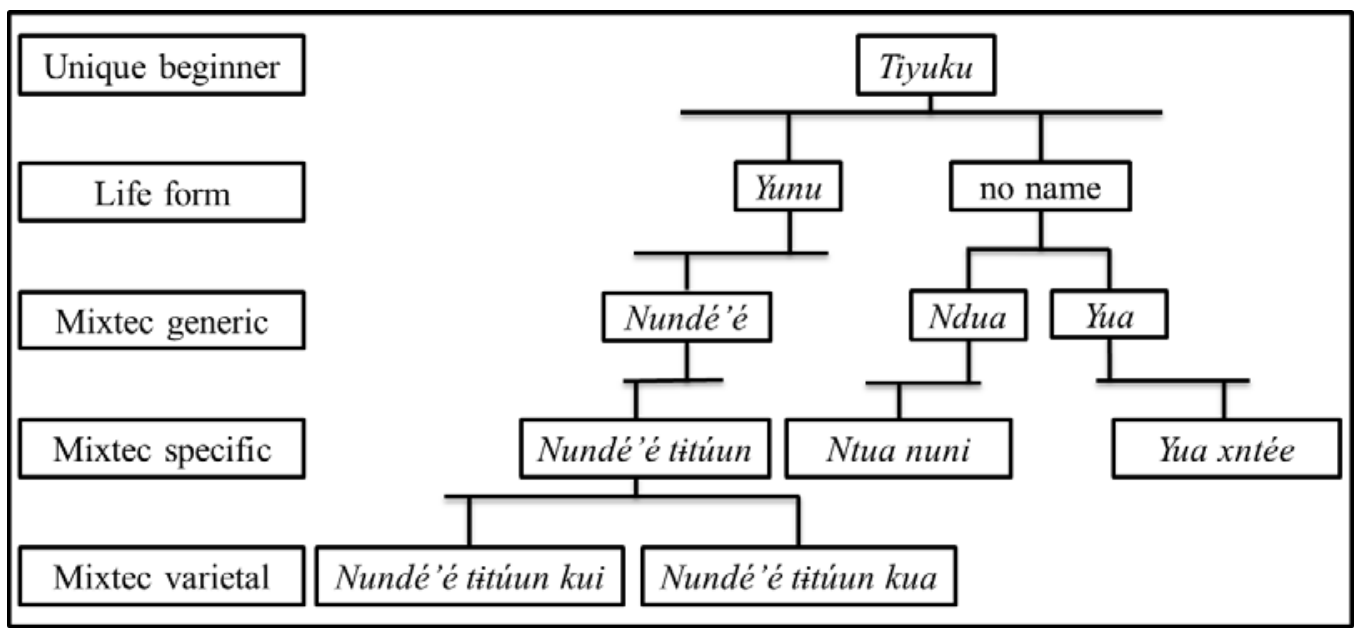

Figure 2. Schematic representation of the categories of the Mixtec classification of plants.

In the previous figure, two Mixtec varieties of a tree with black round fruits are represented, which are grouped together in the Mixtec generic that brings together trees with fruits. Fruit trees are immediately grouped into the tree life form and later to the unique beginner. Edible plants are a form of life that is not linguistically labeled, they are grouped into two Mixtec generics; one refers to plants that are eaten cooked and the other refers to plants that are eaten raw.

The Mixtec classification system of the plants can be analyzed using both an cognitivist approach, as well as a utilitarian approach. It is cognitive because it has a structure that tries to include all the botanical entities in the environment in a vision of order of the natural world (Berlin 1992). For example, the Lupinus montanus Kunth, species (among others) that grows apparently isolated above the $2900 \mathrm{~m}$ MSL, does not have an explicit use attributed to it; however, it is carefully named as ita ntixi ndií--purple corncob flower. The classification is utilitarian because it can form its own categories based on utility, such as those of edible plants. The way that Mixtec classify edible plants is possibly unique, and is essentially based on utility. The interesting thing 
about these categories is that the Mixtec ethnotaxa they include are not classified in other categories. To explore the rigidity of these categories, we tried the following exercise: during the tours we pointed out a feature of an edible plant, but emphasizing the term herb, "look how beautiful the leaf of that herb is" (pointing to Anoda cristata (L.) Schltdl.). Some people did not register any importance and simply confirmed. But others clarified that it was not an herb, but a yua. This shows that in Mixtec idiosyncrasy, an edible plant cannot be just any herb, but it is still a plant, and also that the cognitivist and utilitarian vision of classification can coincide in the same classification system (Clément 1995). These categories that separate plants eaten raw and cooked appear to be consistent in the high Mixtec subregion. At least six towns in this subregion manifest this nomenclature (De Ávila 2010). In San Miguel el Grande these categories include most of the plants that are consumed whole or their leaves, young shoots and flowers. Plants from which only one part is consumed, such as bulbs, flowers or fruits, and those that have double utility as edible and medicinal, have different names.

The previous classification, in some way, includes all the plants in the environment. We must clarify, however, that in this hierarchical classification, some categories of Mixtec generics, especially those that have a use, have unique special names that do not show a subordination to other higher categories. These categories were termed aberrant generics by Berlin (1992), and are common in traditional classifications (Berlin 1973, Brown 2000, Voeks \& Nyawa 2006). However, we cannot call these categories aberrant because Mixtec do not exclude these categories when they think of plants. The Mixtec classification tends to be hierarchical but naturally includes the cultural. There is another independent and outstanding classification that classifies plants by their hot or cold quality, but this classification only includes certain plants (edible and medicinal plants in general). A hot plant is important because it is medicinal; it is used in infusions, or for hot or steam baths. A cold or fresh plant is important because it is used to reduce fever, but perhaps it is more important in the diet since certain people cannot consume it. For example, during childbirth women cannot eat Amaranthus hybridus L. because its cold quality can trigger alterations in the body of the woman and the newborn. But they can eat the Leucaena species after a few days of childbirth because it is a hot plant. A similar hot-cold classification is observed in the Irulas in India, where a pregnant woman should avoid the tender shoots of Phoenix sylvestris because it is a hot plant that can cause abortion of the fetus (Newmaster et al. 2007). The classification in hot and cold plants is relevant in medicinal plants of various cultures (see Alvarez-
Quiroz et al. 2017, Gonzales et al. 2014, GarcíaHernández et al. 2015).

\section{Plant nomenclature}

Mixtec plant names can be made up of simple unitary lexemes, complex unitary lexemes, or compound lexemes. The following table shows examples of the types of lexemes that make up the names.

Table 2. Types of lexemes in Mixtec botanical names.

\begin{tabular}{|c|c|c|}
\hline \multicolumn{3}{|c|}{ Types of lexemes } \\
\hline \multicolumn{2}{|c|}{ Lexemes unitary } & Lexemes \\
\hline Simple & Complex & \\
\hline Taminu & Suma tiñi & Yau kuasu \\
\hline Tindisa & Nu-janu & Yau chuku \\
\hline Tiku & Yaa ina & Yau yuku \\
\hline Titerne & Nchau ñuu & Yau isa \\
\hline
\end{tabular}

As noted earlier, Conklin (1962) proposed the first ethnobiological nomenclature, and he distinguished two types of biological "lexemes" (or, also called, "labels"): "unit lexemes" and "compound lexemes". Unit lexemes can be of two kinds: "simple" and "complex". As we explain it in the methodology, Conklin's essential distinction is that "compound lexemes" exhibit descriptive force while "complex unit lexemes" do not. Berlin et al. (1973), based on Conklin's proposal, added one more distinction that separates complex primary names of productive type and secondary names. These typologies follow a taxonomic criterion-the productive type complexes contain an expression that indicates a superordered category; for example, tuliptree is a kind of tree, pipevine is a kind of vine. Secondary names occur in contrast sets, for instance, black oak contrasts with red oak and white oak. For Berlin et al. (1973), simple unitary names are unanalyzable. We have found all the types of lexemes mentioned by these authors, for example: simple unitary (tintu); complex unitary (yáá ina "dog's tongue"); productive complex unitary (nuyúji); secondary (tínana sóó, tínana kuá'á...). However, the Mixtec language shows an important variation in the way plants are named; the simplest unit lexemes can exhibit descriptive force. This is the case for the name yuxi, which specifically refers to Tillandsia usneoides (L.) L. The word yuxi is itself a specific morphological description of the plant.

The meaning of lexemes in Mixtec names includes various characteristics of the plant, as well as cultural aspects. Morphology is a relevant point. For example, the grasses that make up its name with the adjective lasú that refers to the braids of women's hair in their hairstyles are grasses that have inflorescences formed by spikelets. Several plants with thorns have in their names the word iñ which means thorn. The second name of the Opuntia 
huajuapensis Bravo species is skóó (round) in allusion to its circular cladodes. Color is another adjective widely used in the formation of the binomial names of a large number of plants. It includes several colors as can be seen in table 3 .

Table 3. Colors used in the Mixtec nomenclature of plants.

\begin{tabular}{|l|l|l|}
\hline Color & $\begin{array}{l}\text { Specific I } \\
\text { varietal } \\
\text { mixtec }\end{array}$ & Scientific name \\
\hline White & Yau kuijín & $\begin{array}{l}\text { Agave } \\
\text { americana L. }\end{array}$ \\
\hline Black & Nukava tuun & $\begin{array}{l}\text { Baccharis } \\
\text { conferta Kunth }\end{array}$ \\
\hline Yellow & Ita iñu kuáan & $\begin{array}{l}\text { Solanum } \\
\text { rostratum Dunal }\end{array}$ \\
\hline Red & Nuyuja kuá'á & $\begin{array}{l}\text { Pinus leiophylla } \\
\text { Schiede ex } \\
\text { Schltdl. \& Cham }\end{array}$ \\
\hline Ash grey & Yuku yáá & $\begin{array}{l}\text { Brickellia } \\
\text { veronicifolia } \\
\text { (Kunth) A. Gray }\end{array}$ \\
\hline Green & Yau kui & $\begin{array}{l}\text { Agave salmiana } \\
\text { Otto ex Salm- } \\
\text { Dyck }\end{array}$ \\
\hline Purple & Itá limbée ndíi & $\begin{array}{l}\text { Dahlia pinnata } \\
\text { Cav. }\end{array}$ \\
\hline Blue & Nuni ncháá & $\begin{array}{l}\text { Blue corn } \\
\text { Zea mays L. }\end{array}$ \\
\hline Pinto \\
(multicolor) & Nduchi pintu & $\begin{array}{l}\text { Phaseolus } \\
\text { vulgaris L. }\end{array}$ \\
\hline
\end{tabular}

The name can also refer to the environment where the plant inhabits, such as those that grow on trees, in rivers, or in water such as icha yuchi nducha, "a medicinal herb of water" that refers to a species of the genus Cyperus.

Many plants have an adjective in their names that refers to an animal-by the resemblance, because the animal consumes it, or because it affects it. These can be very specific relationships between species like Schkuhria pinnata (Lam.) Kuntze ex Thell., which is called yuku chó'ó (herb of the flea) because it kills fleas. Only one plant has the name of another plant. This plant is ndua vincha: ndua; "edible plant" and vincha; "nopal" refers to the Peperomia bracteata A.W. Hill, species that the Mixtec relate to plants of the genus Opuntia due to its slimy consistency and its circular leaves.

Mixtec names that present polysemy deserve special attention. An interesting case is the name tinda'á, which refers to a color and which belongs to both a variety of corn and an edible larva, a discussion about it can be seen in Aparicio et al. (2018). The váyá (orange) color is part of the name of the pumpkin flowers and also of an edible mushroom
(Cantharellus cibarius s.l.). The first case seems to only occur in the study municipality, since we have not found it in the bibliography of other Mixtec towns, even in neighboring towns, such as Chalcatongo and Yosondúa (Beaty et al. 2012; Pérez-Jiménez 2017). The second case seems to occur in some communities of the high Mixtec. The Mixtec of the municipality of Santa María Cuquila know the fungus in question as squash flower fungus (Moctezuma 2014), several towns use the term vaya to designate the squash flowers (see De Ávila 2010), while others designate vaya to the same mushroom (Beaty et al. 2012, Katz 1996). These polysemic names account for how Mixtec peoples have shaped the Mixtec language of their local flora from characteristics between species.

In San Miguel el Grande, the coloration pattern and appearance of horsetails (Equisetum) are also compared with some rattlesnakes (Crotalus) and are named under the same name of xi'o koo. A very interesting case is the Mixtec name tisa'á, with which the plants of the genus Phoradendron are named and also to their dispersers, the birds. Mixtec are not strangers to ecological interactions and they know very well both the dispersal process and the characteristics of the fruits that adhere easily to trees. In these interspecific relationships, as Nabhan (2000) supposes, the names of the plants that recognize their faunistic associates are derived from empirical observations of interactions between plants and animals. They are very important for species identification and show how traditional ecological knowledge is important to the understanding of nomenclature.

Localities with plant names also help to understand how the landscape has changed over time. For example, an old name of the municipality of San Miguel el Grande was ñuu itu yuku, supposedly for a medicinal plant that grew in the current seat of the municipality. But today, the oldest Mixtec barely remember that the plant ever lived there. At the same time, worldview is also present in the nomenclature. People perceive plants of the rain (Myriopteris spp.) and the eddies (Selaginella spp.), ferns and spikemosses, as special because they do not resemble the other plants. Both groups of plants are believed to have the supernatural power of exorcising the evil spirits that bring the rain and eddies when they touch humans.

Another group of plants shows the usefulness in their names. For example, several plants have in their name the word ñi'in that refers to the temazcal bath (where steam baths are made). Half of these plants are used during bath rituals, either as infusions that are drunk before entering the bathroom or as branches that are used to distribute steam over the 
body of the person, and the other half are used for later cures related to the discomfort caused by the bathroom, in a very interesting worldview (Figure 3).

Edible plants are the most relevant. They constitute their first binomial name from two words; the first group groups together the plants that are cooked to be eaten (yua) and the second those that are eaten raw (ndua). The second binomial name generally refers to characteristics of the plant or some animal. Table 4 shows examples of edible plants from the two mentioned categories.

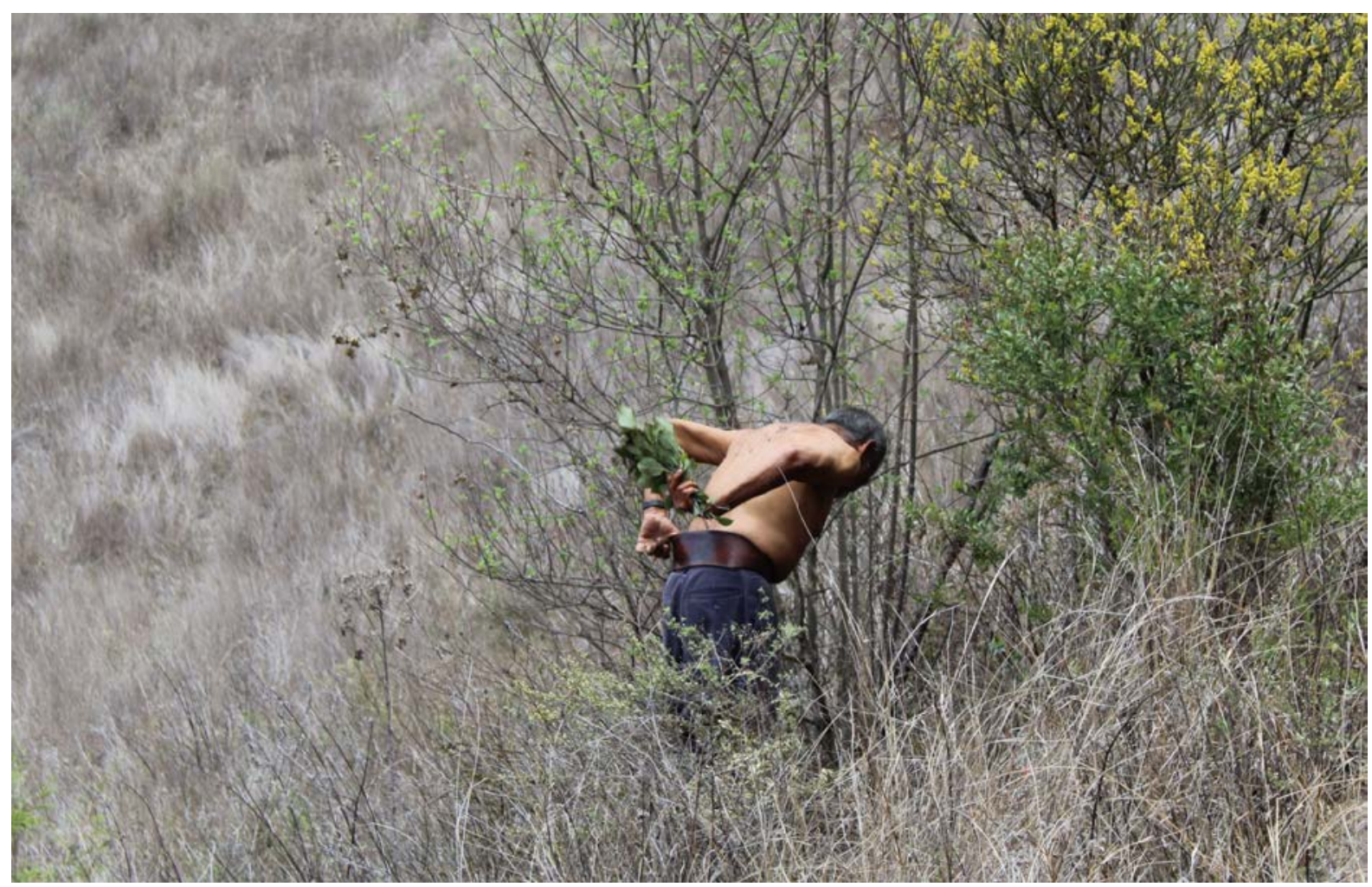

Figure 3. The species Alnus acuminata Kunth, is called nu ñi'in (bath tree). It is used during the temazcal bath and also in later cures related to ailments caused by the temazcal baths. The photo shows a man with branches of $A$. acuminata in a healing ritual in an old temazcal bath.

Table 4. Lexemes of Mixtec edible plants and their Linnaean correspondences.

\begin{tabular}{|l|l|l|l|}
\hline Generic yua & Generic ndua \\
\hline Yua tixinti & $\begin{array}{l}\text { Cyclanthera dissecta (Torr. \& A. } \\
\text { Gray) Arn. }\end{array}$ & Ndua nete & Leucaena cuspidata Standl. \\
\hline Yua xntée & Lopezia racemosa Cav. & Ndua sndiki & Bidens serrulata (Poir.) Desf. \\
\hline Yuá táyóó & Anoda cristata (L.) Schltdl. & Ndua nuni & Peperomia leptophylla Miq. \\
\hline Yuá jiti & Amaranthus hybridus L. & Ndua china & Berula erecta (Huds.) Coville \\
\hline Yua taka & Chenopodium berlandieri Moq. & Ndua ntuú & $\begin{array}{l}\text { Galinsoga quadriradiata Ruiz } \\
\text { \& Pav. }\end{array}$ \\
\hline
\end{tabular}

Some medicinal plants form their names with the term tana which translates as curative. Others are named after the body parts upon which they act, like vein herbs (yuku tuchi--Heimia salicifolia Link), which is believed to act on the veins and numb the body.

The nomenclature implicit in the use of the plant is important for identification. But if the plant use is discontinued, the name loses meaning. For example, the name yau patéé that Agave applanata (Lem. ex Jacobi) is known by refers to its use, patéé is a utensil, equivalent to a tray. The agave in question has its leaves more open (semi-concave) than other species, which is why they were widely used as kitchen utensils and other tasks. Currently the name patéé has no reference for many people, as this 
utility has been abandoned. Another example is Muhlenbergia sp., a grass that was widely used for thatch of houses, and was in the past even cultivated. It is called icha ve'e "grass for house." Nowadays it is no longer used, it is difficult to find, and some Mixtec now call it only icha, a grass. Hunn (1982), in defense of the utilitarian perspective, shows how the Sahaptin of North America more solidly name the plants that provide higher energy yield, while the plants with minimal utility they recognize as "just a flower". In other cases, the cultural importance of plants plays an important role in nomenclature differentiation. For example, in the municipality there are several species of the genus Oxalis. All are known under the Mixtec generic nduxa and all are edible. But only Oxalis corniculata L. differs with the binomial name nduxa iso because it is also an important medicinal plant. However, that does not imply that people are unaware that various species of Oxalis exist, simply that they are only descriptively differentiated.

An important detail regarding species utility is that some plants have two names, but one of them refers to its use. A relevant example is the case of Baccharis pteronioides DC., which is called tikú. Some people, however, call it ndáku, which means "broom," because brooms are made with the plant. However, brooms are also made from its congener, Baccharis conferta Kunth, but this species is not named ndáku. Although many people recognize that ndáku is not the original name of the plant, other people use the name to refer to the living plant and not the broom.

A small number of plants emphasize a special characteristic of the plant such as yuku tixíko which translates to "stinky herb." Casimiroa edulis La Llave, is named as nundoko kusun, in relation to the fact that the fruit and the leaves induce sleep. It is worth mentioning that the Mixtec nomenclature of San Miguel el Grande also exhibits a simplification process in some contexts. For example, it is common for people to use the name ndoko to refer to the $C$. edulis species. However, ndoko is the name of the fruit and not the plant. The name of the tree is nundoko, but some people name both the plant and the fruit as ndoko. This aspect is important from the taxonomic point of view, since as we have seen (Berlin et al. 1973), nu- (wood), is a nominal marker that indicates that ndoko is a tree. Many plant names that apparently have no meaning may have gone through this simplification process. Moreover, it is important to note that all the Mixtec we worked with, on at least one occasion, could not remember the Mixtec name of one or more plants, and that people aged 38 to 60 confused the names of some plants. We believe that this is because today younger people speak more Spanish than Mixtec.
Finally, a significant number of plants structure their names with "loans" from Spanish. These are structured by a Mixtec word and another in Spanish. Also, the word stila is a distinctive marker for plants that have been introduced. Some examples are shown in Table 5.

Table 5. Names borrowed from Spanish in Mixtec botanical nomenclature.

\begin{tabular}{|l|l|l|}
\hline $\begin{array}{l}\text { Mixtec } \\
\text { name }\end{array}$ & Translation & Scientific name \\
\hline $\begin{array}{l}\text { Nundé'é } \\
\text { trasnú }\end{array}$ & Peach tree & $\begin{array}{l}\text { Prunus persica } \\
\text { (L.) Batsch }\end{array}$ \\
\hline Iñu burrú & Donkey thorn & Solanum spp. \\
\hline Naranja íá & Sour orange & $\begin{array}{l}\text { Citrus } x \\
\text { aurantium } \text { L. }\end{array}$ \\
\hline Itá limón & Lemon flower & $\begin{array}{l}\text { Dalea foliosa (A. } \\
\text { Gray) Barneby }\end{array}$ \\
\hline $\begin{array}{l}\text { Yuku } \\
\text { leche }\end{array}$ & Milk herb & Asclepias spp. \\
\hline Yau stila & $\begin{array}{l}\text { Agave of } \\
\text { Castille }\end{array}$ & $\begin{array}{l}\text { Aloe vera (L.) } \\
\text { Burm. f. }\end{array}$ \\
\hline $\begin{array}{l}\text { Yua táyóó } \\
\text { stila }\end{array}$ & - & $\begin{array}{l}\text { Malva parviflora } \\
\text { L. }\end{array}$ \\
\hline
\end{tabular}

The lexeme stila, from Castille, has been documented in the high Mixtec to name introduced plants (Katz 1997). In San Miguel el Grande we find some plants that are named in a similar way, like Aloe which is called yau stila. However, other plants introduced have been lumped in the group of plants with which they share similar characteristics. For example, for the species Pennisetum clandestinum Hochst. ex Chiov., that arrived in the territory in the second half of the last century, we have registered at least two important names for it. It is named as icha ndóó "cane grass" due to its morphology and also icha xii, the word xii, refers to the difficulty of uprooting the plant. But both names are already given to other grass species. It may also be that the excessive presence of the grass is important to its salience and naming. The naming of new species with Mixtec names reflects a cognitive process and a positive adaptation to linguistic change.

We have presented some important features of Mixtec botanical nomenclature at San Miguel el Grande. It is also important, however, not to limit inquiry to the taxonomic perspective, but to include linguistic and cultural aspects as well. The nomenclature gives us clues to the behavior of plant diversity in a given area; it can offer additional data on specific species that can be useful for scientists to apply in the monitoring and conservation of flora. 


\section{Plant identification}

Identification is another interesting area of ethnotaxonomy. Identification through the morphology of the plants is very important; some characteristics are explicit in the name as shown previously, but in others are only possible through a revision of the plant. For example, the Mixtec use the species Galium mexicanum Kunth as medicine, but there is another species of Galium, in this case the species in question is called yuku kishi, which is sticky thanks to its abundant hirsute indumentum. Traditional doctors rely on the indumentum of plants and other morphological characteristics to collect them.

Berlin (1973) reported that taxonomic distinction is based on differences and similarities in the biological attributes of the plant, but morphology only represents one aspect of the picture (Atran 1998, Hunn 1982). There are other complex characteristics and methods that people use to distinguish plants, and these seem to be profoundly influenced by use and experience. For example, the Mixtec generic tiláxún recognizes the species Jaltomata procumbens (Cav.) J.L. Gentry, a plant well known by the community with fruit that is widely consumed. This designation can be deepened by adding to form the binomial tiláxún kuáñúún, that refers to Solanum nigrescens M. Martens \& Galeotti, a plant that is edible but only by some people. If further precision is desired, people add one more designation to form the trinomial tiláxún kuáñúún tana, which recognizes the species Solanum americanum Mill, a plant that is used by traditional doctors to treat important diseases. There is an important local controversy between the two Solanum species because they are very difficult to distinguish through morphology, which is why some people consume them and others do not. Some people consider them toxic, but traditional doctors are easily able to recognize $S$. americanum, using their experience to recognize its general appearance or because they claim that it numbs the mouth when introducing a few leaves for a few minutes.

In addition to morphology, we find other mechanisms for identifying plants. People identify plants by the attributes of their compounds that may or may not affect sensory perception: for the quality, property and attributes of different parts of a plant; due to the organoleptic characteristics such as taste, smell and texture; by the type of soil where it grows; and by gender, "female and male" plants. Also due to the quality of the food that is prepared with them, in this case the performance, appearance, consistency and nutritional value of the different Mixtec ethnotaxa are taken into account.
The use of sensory criteria such as taste and smell to identify plants is common in some cultures in Mexico (Heinrich 1998, Leonti et al. 2002). And in Southeast Asia, the Kenyah LeppòKe of Borneo recognize $92 \%$ of their medicinal plants through sensory properties such as bitterness and astringency (Gollin 2004). In several ethnic groups in Uganda, the morphological and organoleptic variation of the drupes of the shea tree (Vitellaria paraxa subsp. Nilotica) is considered the main basis for distinguishing ethno-varities (Gwali et al. 2011). Organoleptic characteristics are also used in the Himalayas of Nepal to differentiate medicinal plants (Ghimire 2004). Mixtec in our study area commonly use the smell and taste of plants to corroborate their identity. With edible plants something very interesting happens. During the month of July, in the hottest period of the year, people generally inspect the taste of the plants before collecting them for consumption, because high temperatures affect the quality of the plants and that they can affect people if they consume them. Something similar is reported for the Kalimantan of Indonesia, who inspect the smell and taste of plants as a habitual assessment of the surroundings (Gollin 1997).

Maize represents a particularly important example. In the first instance, the Mixtec employ morphology to identify the maize, yellow maize for example, then there are approximately five variations of yellow color (for example; nuni sóó kuáan--"yellow-shelled corn"; nuni yujan kuáan--"yellow-dough corn"; nuni kuáan ndi'--"mince-yellow corn"). The color and size are important, but the consistency, the yield, appearance, and nutritional value of foods prepared with them give each variety a particularly special meaning because it is important in agricultural decisions. Each variety is planted in fields with different exposures, slopes, and soil type because some have different phenologies and are more resistant to drought or pests. Although the latter could be a useful strategy for adapting to climate change, currently the consumption of corn external (maybe transgenic) in the communities is quite evident. The Malayali of India have similar identification criteria, classifying millets by food quality, digestibility, and ecological tolerance (Maloles et al. 2011, Rengalakshmi 2005). Beans are another interesting example because they show that the type of soil where the plants grow influences the quality of the products. The same beans can be planted in two different fields but the cooking is not the same. The Kattunaikka, another group from India, identify their plants of the genus Dioscorea based on growth habit and cooking (Balakrishnan et al. 2003).

The Mixtec recognize a number of species with two or more Mixtec names. Some of these species are 
Phragmites australis (Cav.) Trin. ex Steud., Prunus serotina Ehrh., Agave salmiana Otto ex Salm-Dyck, Agave atrovirens Karw. ex Salm-Dyck, and some shrubs. Some herbaceous plants are also identified as two or more varieties but generally do not present a name. Rather, their differences are simply explained verbally. According to Berlin 1992, this relationship is called over-differentiation, and generally occurs among organisms that are culturally significant for utilitarian or cognitive reasons. The utilitarian reason is perhaps more important in the Mixtec case. $P$. australis, for example, which is named nuyoo, has three Mixtec varieties. Nuyoo yuku is characterized by being small, thin, and only growing in the rainy season. Nuyoo ntagua is a plant with very tough stems and has been used mainly for the roofing of houses. Nuyoo vita is characterized by its soft stems; it has been used, but to a lesser extent today, to make various types of local baskets. The last two are clearly distinguished because one cannot substitute for the usefulness of the other. Another case is that of $P$. serotina. This species is not differentiated by the plant (leaf and stem) but if by the fruits, three Mixtec varieties are differentiated, the main differences that are taken into account are the flavor, size of stone and fruit, and the coloring of the fruit. Interestingly, both $P$. australis and $P$. serotina are historically problematic species. $P$. australis has more than one hundred synonyms and currently only three subspecies have been recognized (Saltonstall et al. 2004). P. serotina forms a botanical complex of five subspecies with strong delimitation ambiguities (Guzmán et al. 2020). These observations of over-differentiation have been observed since Conklin (1954) with the Hanunoo of the Philippines, who recognized a quarter more taxa in relation to the Linnaean species identified. Traditional identification and nomenclature mechanisms are important because they have been shown to reveal new scientific species (Newmaster et al. 2009) as well as clarify complexes of cryptic species (Cheng et al. 2020, Newmaster \& Ragupathy 2010). A detailed analysis of the ethnotaxa and the Mixtec identification in relation to Linnaean species can complement the work of taxonomists, as well as help to record new scientific knowledge in an area little studied from a biological diversity point of view.

\section{Conclusion}

This study has managed to present an overview of the ethnotaxonomy of plants in the Mixtec municipality of San Miguel el Grande. There is a more or less hierarchical classification that can be analyzed with cognitive and utilitarian aspects that includes all the plants collected in this study. The Mixtec classification is an example that traditional classification systems can include different views (cognitivist, utilitarian) in a single model since people do not have these visions in mind when they think of plants as a whole. Nomenclature has been modified from observations and experiential interactions with plants. Mixtec identification comprises multiple mechanisms that include morphological, ecological, cultural, and experiential aspects.

The results that we have presented in this document show, although partially, that Mixtec ethnotaxonomy is rich, which allows us to suppose that in-depth analyzes of nomenclature and identification can be useful to evaluate local botanical diversity, as well as other factors related to the use and conservation of mixtec plants. However, we must warn that the fact that the names of the plants tend to be forgotten by people, supposes a change in the local botanical ethnotaxonomy.

\section{Declarations}

Ethics approval and consent to participate: All the participants provided prior informed consent before the interviews.

Consent

Consent for publication: The person represented in Figure 2 gave his consent for the publication of the image.

Availability of data and materials: Data are available from the first author.

Competing interests: The authors declare that they have no competing interests.

Authors' contributions: JCAA carried out the field research and drafted the manuscript. RV and LSF participated in its design and coordination, and thoroughly revised the manuscript. All authors read and approved the final manuscript.

\section{Acknowledgments}

This paper is part of the PhD thesis of the first author prepared in the Programa de Pós-graduação em Botânica of Universidade Estadual de Feira de Santana, Bahia, Brazil (PPGBot-UEFS). The research is partially funded by a grant from the National Council of Science and Technology (CONACYT). The authors thank all the Mixtec who participated in the research and the community authorities for their willingness.

\section{Literature cited}

Alvarez-Quiroz VL, Caso-Barrera M, AliphatFernández, Galmiche-Tejeda A. 2017. Plantas medicinales con propiedades frías y calientes en la cultura Zoque de Ayapa, Tabasco, México. Boletín Latinoamericano y del Caribe de Plantas Medicinales y Aromáticas 16:428-454.

Aparicio JC, Costa-Neto EM, Paulino de Araújo G. 2018. Etnotaxonomía mixteca de algunos insectos en el municipio de San Miguel el Grande, Oaxaca, México. Revista Etnobiología 16:58-75. 
Aparicio JC. 2019a. La milpa: un agroecosistema tan fuerte para la unificación comunitaria y tan débil contra las afluencias del cambio climático en la subregión fría de la mixteca alta de Oaxaca, México. Documento presentado en el VI Congreso Latinoamericano de Etnobiología. Sucre Bolivia.

Aparicio JC. 2019b. Taxonomía mixteca y usos de los hongos en San Miguel el Grande, Oaxaca, México. Revista etnobiología 17:19-30.

Atran S. 1998. Folk biology and the anthropology of science: cognitive universals and cultural particulars. Behavioral and Brain Sciences 21:547-609.

Bertoni MS. 1940. Diccionario Botánico LatinoGuaraní \& Guaraní-Latino con un glosario de vocablos y elementos de la nomenclatura botánica. Guaraní, Asunción.

Barbosa-Rodrigues J. 1992. A Botânica, nomenclatura Indígena e Seringueiras. Edição comemorativa do Sesquicentenário de João Barbosa Rodrigues, Jardim Botânico de Rio de Janeiro, Rio de Janeiro, Brasil.

Boster JS. 1985. Requiem for the omniscient informant: there's life in the old girl yet. In Directions in cognitive anthropology. Edited for J. Dougherty. University of Illinois Press, Illinois, Pp.177-197.

Brown $\mathrm{CH}$. 1985. Modes of subsistence and folk biological taxonomy. Current Anthropology 26:4364.

Berlin B. 1973. Folk Systematic in Relation to Biological Classification and Nomenclature. Annual Review Ecology and Systematic 4:259-271.

Berlin B. 1992. Ethnobiological Classification: Principles of Categorization of Plants and Animals in Traditional Societies. Princeton University Press, Princeton.

Berlin B, Breedlove DE, Raven PH. 1973. General Principles of Classification and Nomenclature in Folk Biology. American Anthropologist 75:214-242.

Brown CH. 2000. Folk classification: an introduction. In Ethnobotany: a reader. Edited by PE Minis. University of Oklahoma Press, Norman, Pp.65-68.

Balakrishnan V, Ratheesh-Narayanan MK, AnilKumar N. 2003. Ethnotaxonomy of Dioscorea among the Kattunaikka people of Wayanad District, Kerala, India. Plant Genetic Resources Newsletter 135:2432.

Bravo-Hollis H. 1978. Las cactáceas de México. Universidad Nacional Autónoma de México, México.

Beaty K, García P, García R, Ojeda J, San Pablo A, Santiago A. 2012. Diccionario Básico del Mixteco de Yosondúa. Instituto Lingüístico de verano (ILV), Oaxaca, México.

Clément D. 1995. Why is taxonomy utilitarian? Journal of Ethnobiology 15:1-44.

Calderón de RG, Rzedowski J. 2001. Flora fanerogámica del Valle de México. Instituto de
Ecología AC, Centro Regional del Bajío, y Comisión Nacional para el Conocimiento y Uso de la Biodiversidad, $2^{\mathrm{a}}$ edición, Pátzcuaro, Michoacán, México.

Costa-Neto EM, Aparicio JC. 2018. Usos tradicionales de los "insectos" por los mixtecos del municipio de San Miguel el Grande, Oaxaca México. Ethnoscientia 3:1-18.

Cano-Contreras EJ, Medinaceli A, Sanabria-Diago OL, Argueta A. 2015. Código de ética para la investigación, la investigación-acción y la colaboración etnocientífica en América Latina. Revista Etnobiología 13:1-28.

Conklin HC. 1954. The relation of Hanunoo culture to the plant world. Doctoral Dissertation. Yale University, New Haven, US.

Conklin HC. 1962. The lexicographical treatment of folk taxonomies. International Journal of American Linguistics 28: 119-141.

Cheng Z, Shu H, Zhang S, Luo B, Gu R, Zhang R, Ji Y, Li F, Long C. 2020. From Folk Taxonomy to Species Confirmation of Acorus (Acoraceae): Evidences Based on Phylogenetic and Metabolomic Analyses. Frontiers in Plant Science 11:965.

De Ávila A. 2010. Mixtec plant nomenclature and classification. Doctoral Dissertation. University of California, Berkeley, US.

Farjon A, Pérez de la Rosa JA, Styles BT. 1997. Guía de campo de los pinos de México y América Central. The Royal Botanical Gardens, Kew, United Kingdom.

Gollin LX. 1997. Having your medicine and eating it too: A preliminary look at medicine and meals in Kayan-Mentarang, Kalimantan, Indonesia. Borneo Research Bulletin 28:28-41.

Gollin LX. 2004. Subtle and profound sensory attributes of medicinal plants among the Kenyah Leppo Ke of East Kalimantan, Borneo. Journal of Ethnobiology 24:173-201.

Gentry HS. 1982. Agaves of Continental North America. University of Arizona Press, US.

García E. 2004. Modificaciones al sistema de clasificación climática de Köppen, 5ta edición. Universidad Nacional Autónoma de México, México.

Gwali S, Okullo J, Eilu G, Nakabonge G, Nyeko P, Vuzi P. 2011. Folk Classification of Shea Butter Tree (Vitellaria paradoxa subsp. nilotica) Ethno-varieties in Uganda. Ethnobotany Research \& Applications 9:243-256.

Ghimire SK, McKey D, Aumeeruddy-Thomas Y. 2004. Heterogeneity in ethnoecological knowledge and management of medicinal plants in the Himalayas of Nepal: Implications for conservation. Ecology and Society 9:6-6.

García-Hernández KY, Vibrans H, Rivas-Guevara M, Aguilar-Contreras A. 2015. This plant treats that 
illness? The hot-cold system and therapeutic procedures mediate medicinal plant use in San Miguel Tulancingo, Oaxaca, Mexico. Journal of Ethnopharmacology 163:12-30.

Gonzales M, Baldeón S, Beltrán H, Jullian V, Bourdy G. 2014. Hot and cold: medicinal plant uses in Quechua speaking communities in the high Andes (Callejón de Huaylas, Ancash, Perú). Journal of Ethnopharmacology 155:1093-1107.

Guzmán FA, Segura-Ledesma SD, AlmaguerVargas G. 2020. El capulín (Prunus serotina Ehrh.): árbol multipropósito con potencial forestal en México. Madera y bosques 26:4.

Galeano G. 2000. Forest use at the Pacific Coast of Chocó, Colombia: a quantitative approach. Economic Botany 54:358-376.

Hunn E. 1982. The utilitarian factor in folk biological classification. American Anthropologist 84:830-847.

Hays TE. 1982. Utilitarian/adaptationist explanations of folk biological classification: Some cautionary notes. Journal of Ethnobiology 2:89-94.

Heinrich M. 1998. Indigenous concepts of medicinal plants in Oaxaca, Mexico: Lowland Mixe plant classification based on organoleptic characteristics. Journal of Applied Botany 72:75-81.

Instituto Nacional de Lenguas Indígenas. 2010. Programa de Revitalización, Fortalecimiento y Desarrollo de las Lenguas Indígenas Nacionales 2008-2012. Diario Oficial de la Federación. México.

Instituto Nacional de Estadística y Geografía (INEGI). 2005. Geoestadístico municipal. Oaxaca.

Instituto Nacional de Estadística y Geografía (INEGI). 2010. Censo de población y vivienda. México.

Katz E. 1996. La influencia del contacto en la comida campesina mixteca. In: Conquista y comida consecuencias del encuentro de dos mundos. Editado por Long J. Universidad Nacional Autónoma de México, México, Pp.339-3623.

Katz E. 1997. Las plantas exógenas en la taxonomía Mixteca (México). Actas Etnobotánica 92:53-58.

Kakudidi EK. 2004. Folk plant classification by communities around Kibale National Park, western Uganda. African Journal of Ecology 42:57-63.

Leonti M, Sticher O, Heinrich M. 2002. Medicinal plants of the Popoluca, Mexico: Organoleptic properties as indigenous selection criteria. Journal of Ethnopharmacology 81:307-315.

Moctezuma A. 2014. El guajolote en el Sistema de traspatio: producción e importancia cultural en la comunidad mixteca Ñuu kuiñi - Santa María Cuquila, Tlaxiaco, Oaxaca. Tesis de licenciatura. Facultad de ciencias, Universidad Nacional Autónoma de México, México.

Maloles JR, Berg K, Ragupathy S, Nirmala BC, Althaf KA, Palanisamy VC. 2011. The fine scale ethnotaxa classification of millets in southern India. Journal of Ethnobiology 31:262-287.

Newmaster SG, Ragupathy S, Balasubramanian NC, Ivanoff RF. 2007. The Multi-Mechanistic Taxonomy of the Irulas in Tamil Nadu, South India. Journal of Ethnobiology 27:233-255.

Newmaster SG, Murugesan M, Ragupathy S, Velusamy B. 2009. Ethnobotany Genomics Study Reveals Three New Species from the Velliangiri Holy Hills in the Nilgiri Biosphere Reserve, Western Ghats, India. Ethnobotany 21:2-24.

Newmaster SG, Ragupathy S. 2010. Ethnobotany genomics - discovery and innovation in a new era of exploratory research. Journal of Ethnobiology and Ethnomedicine 6:2.

Nabhan GP. 2000. Interspecific relationships affecting endangered species recognized by O'odham and Comcáac cultures. Ecological Applications 10:1288-1295.

Pérez-Jiménez GA. 2003. Sahìn Sàu. Curso de Lengua Mixteca (variante de Ñuù Ndéyá). Universidad de Leiden, Holanda.

Rengalakshmi R. 2005. Folk Biological Classification of Minor Millet Species in Kolli Hills, India. Journal of Ethnobiology 25:59-70.

Saltonstall K, Peterson PM, Soreng RJ. 2004. Recognition of Phragmites australis subsp. americanus (Poaceae: Arundinoideae) in North America: evidence from morphological and genetic analyses. SIDA, Contributions to Botany 21: 683692.

Tyler SA. 1969. Cognitive Anthropology. Holt, Rinehart, and Winston, New York.

Voeks R, Nyawa S. 2006. Dusun ethnobotany: Forest knowledge and nomenclature in northern Borneo. Journal of Cultural Geography 23:1-31. 